\title{
Transmission and host range of Horsegram yellow mosaic virus (HgYMV) causing common bean (Phaseolus vulgaris L.) yellowing disease in Sri Lanka
}

\author{
R Rienzie ${ }^{1,2}$, DM De Costa ${ }^{1,3}$ and WART Wickramaarachchi ${ }^{4^{*}}$ \\ ${ }^{I}$ Postgraduate Institute of Agriculture, University of Peradeniya, Peradeniya. \\ ${ }^{2}$ Agribusiness Centre, Faculty of Agriculture, University of Peradeniya, Peradeniya. \\ ${ }^{3}$ Department of Agricultural Biology, Faculty of Agriculture, University of Peradeniya, Peradeniya. \\ ${ }^{4}$ National Plant Quarantine Service, Department of Agriculture, Canada Friendship Road, Katunayake.
}

\begin{abstract}
The common bean (Phaseolus vulgaris L.) yellowing disease (BYD) is caused by the Horsegram yellow mosaic virus (HgYMV), which is a begomovirus transmitted by whiteflies (Bemisia tabaci Genn.). It is a serious threat to the common bean cultivation in Sri Lanka. Despite the fact that the disease has been affecting bean production for a long time, its etiology and virus vector relationships are not understood well. Therefore, the present work was carried out to identify major aspects of the etiology of the virus. Initially a survey was conducted to determine the prevalence of the virus in representative bean growing locations in Sri Lanka, followed by a host range study using 54 plant species. Characteristics of virus-vector relationships were determined by conducting a series of virus transmission tests under glass-house conditions. The survey results revealed the incidence of BYD at some time or the other in most of the sampled localities, which are scattered around all four major districts where the common bean is grown. Through the host range study, it was demonstrated that Ageratum sp., Glycine max Merrill., Macrotyloma uniflorum (Lam.) Verdc., and Phaseolus lunatus L. are susceptible to $\mathrm{HgYMV}$, indicating a narrow host range. In addition to the symptomatology, the successful entry of the virus following inoculation was confirmed through PCR using degenerate primers. Relative transmission efficiency was found to be $96.7 \%$, which corresponds to 0.24 of the estimated probability of transmission through a single whitefly $\left(\mathrm{p}^{*}\right)$. The virus could be transmitted through probing by a single viruliferous whitefly with an incidence of $36.7 \%\left(\mathrm{p}^{*}=0.37\right)$. The minimum acquisition access period and inoculation access period were $20 \mathrm{~min}$ in each case and the respective disease incidence values
\end{abstract}

were $30.0 \%\left(\mathrm{p}^{*}=0.04\right)$ and $36.7 \%\left(\mathrm{p}^{*}=0.05\right)$. The whiteflies could retain the virus in an active state for up to 9 days.

Keywords: Begomovirus, Bemisia tabaci Genn., common bean yellowing disease, Horsegram yellow mosaic virus (HgYMV), host range, virus transmission.

\section{INTRODUCTION}

Begomoviruses transmitted by the whitefly, Bemisia tabaci Genn. (Hemiptera: Aleyrodidae) (Bt), are becoming serious threats to agriculture in the world due to the devastating effect they have on an array of economically important crops (Rojas et al., 2018). An attack by any of these viruses can result in yield losses that can range from $0 \%$ to $100 \%$ (Briddon et al., 2001; Legg \& Fauquet, 2004; Navas-Castillo et al., 2011). Adaptability to diverse geographical regions and climates (Costa, 1976; Andret-Link \& Fuchus, 2005; Navas-Castillo et al., 2011) and to a broad host range (Nene, 1972; Harrison, 1985), has favoured the spread of begomoviruses throughout the world. Not only do the characteristics of the vector favour the distribution, but also the ability of the virus to mutate could be the reason behind the increasing host range with the passage of time. Horsegram yellow mosaic virus (HgYMV) infection in horsegram was first reported in India by

*Corresponding author (wartwa@gmail.com; (iD https://orcid.org/0000-0002-5125-1091) 
William et al. (1968). HgYMV was known to be a major virus that affected horsegram but now it is found to be infecting legume crops including common beans (Phaseolus vulgaris L.) (Muniyappa et al., 1987). In Sri Lanka, common beans are extensively grown in different agro climatic regions as a cash crop because it is popular among people due to its nutritional properties. Badulla, Nuwara-Eliya, Matale and Kandy districts have been identified as the major common bean growing districts due to their climate being favourable for the crop. Although systematic statistics on crop losses caused by particular plant viruses are not available in Sri Lanka, HgYMV is considered as a major virus affecting common beans, with losses that can go up to 50 \% (Wickramaarachchi et al., 2012; Rienzie et al., 2016). Common bean yellowing disease (BYD) is currently widespread throughout the traditional bean growing areas. BYD was first recorded in Sri Lanka in 1999 in the Balangoda area, but the precise causal agent was identified only about a decade later. Monger et al. (2010) confirmed that the causal agent was HgYMV, which is a whitefly transmitted begomovirus of the family Geminiviridae. The disease initiates with the mild yellowing of immature leaves, followed by progressing into a mosaic pattern, which appears as irregular mottling interspersed with greenish areas. In time, these mottles develop and turn into large patches. Subsequently, the leaves become smaller and the pod length and size also reduce. Overall, the plant becomes stunted (Muniyappa \& Reddy, 1976; Muniyappa et al., 1987; Prema, 2013).

Information on the distribution and etiology of a disease can be useful to develop management packages designed to control the spread of a disease. Accordingly, the present research was designed to determine the occurrence of the virus in common bean cultivations, and the relationships between the virus, vector and its hosts, by performing a series of experiments. This research would be the first attempt at conducting a detailed study, revealing the nature of transmission of $\mathrm{HgYMV}$ in Sri Lanka.

\section{METHODOLOGY}

\section{Survey on common bean yellowing disease (BYD) in} Sri Lanka

A survey was conducted to determine the prevalence and distribution of BYD in Sri Lanka during the period 2016-2018. Tender leaf samples of the common bean, of both pole and bush type bean cultivars, showing typical BYD symptoms were collected from 20 commercial farmer fields located in different administrative districts of Sri Lanka, namely, Kandy, Matale, Nuwara Eliya and Badulla. A purposive sampling procedure was employed using lists of infected fields provided by the Agriculture Officers of the respective areas. A single plant was considered as a sampling unit. A total of five samples, each comprising two tender leaves, were collected from each of the 20 farmer fields (total of 100 samples). Leaf samples from apparently healthy plants of the same cultivars were also collected from the same locations as control samples. All the leaf samples were collected irrespective of their growth stage but from those plants grown within the same growing season.

\section{Study sites and establishment of Bemisia tabaci colonies for transmission tests}

Bemisia tabaci were reared in the divisions of Plant Pathology and Entomology of the Horticultural Crops Research and Development Institute (HoRDI) in Gannoruwa, Sri Lanka. All transmission experiments were done in the glass houses and insect cages of HoRDI and the Department of Agricultural Biology, University of Peradeniya, Sri Lanka. The sites are located in the mid country wet zone $\left(\mathrm{WM}_{2 \mathrm{~b}}\right)$ with a height above mean sea level of $576 \mathrm{~m}$, mean annual temperature of $24^{\circ} \mathrm{C}$ and mean annual rainfall of $2131 \mathrm{~mm}$. The colonies were maintained at $79-82 \%$ relative humidity and temperature $24-27^{\circ} \mathrm{C}$, under 12L ( $\left.4000 \mathrm{Lux}\right): 12 \mathrm{D}$ lighting throughout the experiment period. The whiteflies were reared on cotton seedlings as they are immune to HgYMV.

\section{Test plants for inoculation purposes}

Seeds of all the weed and crop species and common bean plants used for all the transmission tests were sown in pots, which contained sterilised soil and then maintained inside insect-proof cages at the Division of Plant Pathology, Horticultural Crop Research and Development Institute, Gannoruwa, Sri Lanka.

Testing for cross transmission ability of the virus among different crop and weed plants

Testing for susceptibility to BYD was conducted using 33 crop species and 14 weed species that belong to various families. Both weed and crop species were selected based on the abundance, growth patterns (perennial or annual) and previous reports on begomovirus infestations. All the healthy test plants were inoculated with viruliferous $B t$ fed on HgYMV-infected common bean plants, which were maintained as source plants for $24 \mathrm{~h}$ at a rate of $10 \mathrm{Bt}$ per plant and kept under insect proof conditions 
for another $24 \mathrm{~h}$. The time periods ( $24 \mathrm{~h}$ ) for inoculation access period (IAP) and acquisition access period (AAP) mentioned here and the tests that are described hereafter were selected considering the minimum acquisition and inoculation access periods reported on begomoviruses. The methods employed here are similar to those used by other researchers in this field (Nene, 1972; Inoue-Nagata et al., 2007).

\section{Extraction of total DNA, amplification of target DNA and partial sequencing}

Total DNA from plant tissues were extracted according to the CTAB (cetyl trimethyl ammonium bromide) extraction protocol as described by Lodhi et al. (1994) with a few modifications and subjected to PCR amplification. Previously optimised Begomovirus specific degenerate primer pair, Deng 540/541 (Deng et al., 1994) (Promega, WI, USA) was used at a concentration of 1/25 (DNA: sterile water). The amplified DNA resulting from the initial DNA collected from symptomatic host plants (legumes) was tested for virus transmissibility and subjected to further analysis through single directional sequencing.

\section{PCR amplification mixture (1 X)}

A $25 \mu \mathrm{L}$ reaction mixture that contained $2.0 \mu \mathrm{L}$ of total DNA extracted from infected common bean leaf tissues was prepared. This mixture was diluted to $1 / 25$ (80-100 ng) and to this was added $0.2 \mu \mathrm{L}$ Taq DNA polymerase $(5 \mathrm{U} / \mu \mathrm{L}), 2.5 \mu \mathrm{L}$ of $10 \mathrm{X}$ PCR buffer $(100 \mathrm{mM}$ Tris- $\left.\mathrm{HCl}, \mathrm{pH} 8.3,500 \mathrm{mM} \mathrm{KCl}, 15 \mathrm{mM} \mathrm{MgCl}_{2}\right), 0.5 \mu \mathrm{L}$ of $25 \mathrm{mM} \mathrm{MgCl}_{2}, 2.0 \mu \mathrm{L}$ each primer $(10 \mathrm{mM}), 2.0 \mu \mathrm{L}$ dNTPs mix (2.5 mM each) and sterile water to make up the volume.

\section{PCR conditions}

PCRs with Deng primers were conducted in a thermocycler (Labnet Inc., USA, Model: Labnet Gradient). The mixture was subjected to one cycle of initial denaturation at $94^{\circ} \mathrm{C}$ for $5 \mathrm{~min}$ followed by 30 cycles of denaturation at $94^{\circ} \mathrm{C}$ for $30 \mathrm{~s}$, annealing at $58^{\circ} \mathrm{C}$ for $30 \mathrm{~s}$, extension at $72^{\circ} \mathrm{C}$ for $45 \mathrm{~s}$ and a final extension at $72^{\circ} \mathrm{C}$ for $10 \mathrm{~min}$. The PCR products were analysed by performing $1.0 \%$ agarose gel electrophoresis at $60 \mathrm{~V}$ for $1 \mathrm{hr}$ in $1 \mathrm{X}$ TBE buffer [100 mM Tris ( $\mathrm{pH}$ 8), boric acid, 0.5 M EDTA (pH 8)] with a loading of $5.0 \mu \mathrm{L}$ of product per well. The gel was previously stained with ethidium bromide at $0.5 \mu \mathrm{g} / \mathrm{mL}$. The size of the amplicons was estimated with a 100 bp DNA ladder (Vivantis, Germany). DNA from healthy plants and double distilled water were used instead of template DNA as experimental controls.

\section{Relative transmission efficiency}

Non-viruliferous $B t$ were allowed to feed on BYD infected common bean plants inserted into a transmission cage for $24 \mathrm{~h}$. This feeding time was determined based on the maximum time taken to acquire the viruses. After $24 \mathrm{~h}$, the insects were released onto ten 12-day-old healthy common bean seedlings (per replicate) inserted into individual transmission cages at a rate of $10 \mathrm{Bt}$ per seedling and the test was triplicated. After $24 \mathrm{~h}$, the $B t$ were removed from individual plants and the plants were sprayed with Imidachloprid (Admire ${ }^{\circledR}$, Bayer Crop Sci.) at $200 \mathrm{~g} / \mathrm{L} \mathrm{SL}(1 \mathrm{~mL} / \mathrm{L})$. Plants were maintained under insect-proof conditions until the development of virus infection-like symptoms.

\section{Minimum number of Bemisia tabaci adults required for transmission}

This experiment was designed to determine the minimum number of $B t$ individuals required for successful transmission of the virus and the effects of different numbers of $B t$ to the rate of transmission. Nonviruliferous $B t$ were first fed on diseased common bean leaves for $24 \mathrm{~h}$ as in the previous experiment. Here the $B t$ were released onto seven 12-day-old healthy common bean seedlings inserted into transmission cages at rates of $1,3,5,10,15,20$, and 25 insects per seedling at the rate of three replicates each (total of 21 plants). Next, they were allowed to feed on inoculated seedlings for another $24 \mathrm{~h}$. On the following day (after $24 \mathrm{~h}$ ), the cages were removed and the plants were sprayed with Imidachloprid (Admire $^{\circledR}$, Bayer Crop Sci.) at $200 \mathrm{~g} / \mathrm{L} \mathrm{SL}(1 \mathrm{~mL} / \mathrm{L})$ to kill the $B t$. Plants were kept inside an insect-proof glasshouse until the symptoms developed.

\section{Minimum acquisition access period (AAP)}

This experiment was aimed at determining the minimum time taken by non-viruliferous $B t$ to acquire the virus from a virus-infected plant and the effects of different acquisition access periods on the rate of transmission. $B t$ were fed on infected common bean leaves for periods of 5, 10, 15, 20 and $30 \mathrm{~min}$ and 1, 2, 4, 6, 8, 24 and $48 \mathrm{~h}$. After the prescribed feeding period, $B t$ were transferred at the rate of $10 \mathrm{Bt}$ per seedling onto twelve healthy 12-day-old common bean seedlings covered with micro transmission cages and left for feeding for $24 \mathrm{~h}$ with three replicates. This test was conducted with a total of 36 plants (12 time periods $\times 3$ replicates). Thereafter, the plants were sprayed with Imidachloprid at the same rate as given in the above test and kept for symptom development. The control experiment consisted of 10 plants inoculated with non-viruliferous $B t$ at the rate of 10 Bt per seedling. 


\section{Minimum inoculation access period (IAP)}

The aim of this experiment was to determine the minimum time taken by viruliferous $B t$ to inoculate the virus into healthy common bean plants and the influence of different IAPs on transmission of BYD. First, the nonviruliferous whitefly individuals were given acquisition feeding on diseased common bean leaves for a period of $24 \mathrm{~h}$. Then, the resulting viruliferous $B t$ were transferred onto twelve, 12-day-old healthy common bean seedlings and covered with transmission cages for periods of 5,10 , 15,20 and 30 min and 1, 2, 3, 6, 8, 24 and $48 \mathrm{~h}$ at a rate of $10 \mathrm{Bt}$ per seedling with three replicates. This test was also done with a total of 36 plants (12 time periods $\times$ 3 replicates). After each feeding period, the cages were removed and the plants sprayed with Imidachloprid as in previous tests and maintained in an insect-proof glasshouse until the appearance of symptoms.

\section{Persistence of the virus in the vector}

To determine the persistence of the virus in Bt, a non-viruliferous experiment was designed in which the inoculation of healthy common bean plants was conducted through serial transmission using groups of $B t$ infected with HgYMV. Bt were first given an AAP of $24 \mathrm{~h}$ on BYD infected common beans. Then $B t$ from 12 groups were transferred at the rate of $10 \mathrm{Bt}$ from each group onto 12 common bean plants (each plant was 14 days old at the time of transferring) over a period of $24 \mathrm{~h}$ for each plant. After $24 \mathrm{~h}$, each group was transferred to another set of 12 new and healthy common bean plants. In this manner, the serial transmission procedure was employed for all groups while maintaining all plants inside an insect-proof glass-house until the development of symptoms. Serial transferring was carried out until all the insects of each group were dead. The serial transmission efficiency was calculated using the formula, (Number of infected bean plants in the series/ Number of inoculated plants $\times 100$. The rate of infection per group of $B t$ was determined by simply calculating the average of the sum of serial transmission rates for all groups. Further, the transmission rates corresponding to each date were also calculated by dividing the sum of transmission by the number of groups (12).

\section{Calculation of transmission rate}

Transmission rate was calculated by the formula, Number of infected plants/ Number of test plants $x$ 100. Probability of HgYMV transmission through a single whitefly was calculated using the formula $\mathrm{p}^{*}=1-(1-\mathrm{R} / \mathrm{N})^{1 / \mathrm{i}}$ suggested by Gibbs and Gower (1960) (where $\mathrm{p}^{*}=$ Estimated transmission rate for a single whitefly, $\mathrm{R}=$ Number of infected plants, $\mathrm{N}=$ Number of test plants, and $\mathrm{i}=$ Number of $B t$ per receptor plant). The means were analysed using the least significant difference method (LSD) at $(\mathrm{p}<0.05)$.

\section{RESULTS AND DISCUSSION}

\section{BYD survey}

The survey was conducted to detect the disease using symptomatological features such as severity of yellowing (e.g. bright yellowing or mild yellowing), rugosity and reduced leaf size, which are characteristics of BYD. The results are summarised in Table 1 with sampling locations, which are also mapped in Figure 1.

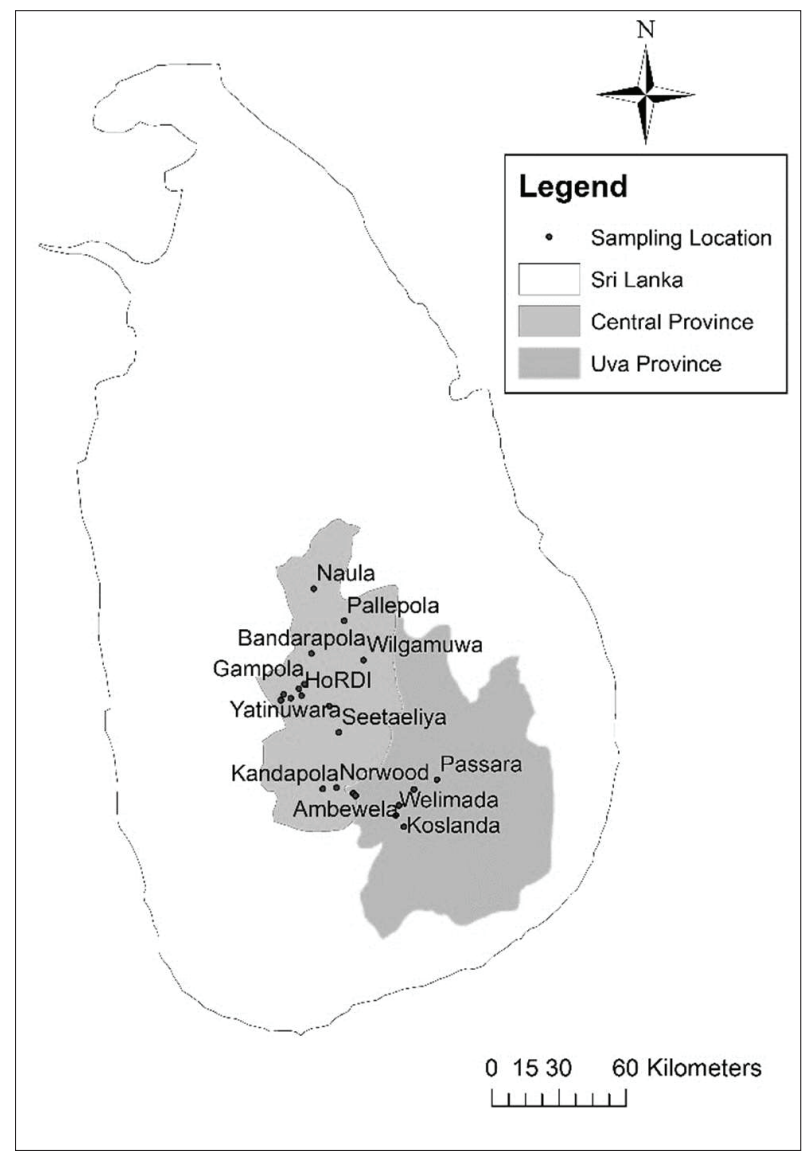

Figure 1: Sampling locations for collecting BYD in Sri Lanka during 2016-2018 period 
Table 1: Results of the diagnosis based on symptomatology of commercial varieties of the common bean

\begin{tabular}{llll}
\hline District & Location & Variety & Symptoms \\
\hline Kandy & Kadugannawa & Contender & BY, R, RL \\
Kandy & Yatinuwara & Contender & BY, R, RL \\
Kandy & Ambilmeegama & Keppetipola Nil & BY, R, RL \\
Kandy & Katugasthota & Top Crop & BY, R, RL \\
Kandy & Gampola & Keppetipola Nil & MY, RL \\
Matale & Bandarapola & Top Crop & MY, RL \\
Matale & Naula & Top Crop & MY, RL \\
Matale & Pallegama & Unknown & BY, R, RL \\
Matale & Wilgamuwa & Unknown & BY, R, RL \\
Matale & Pallepola & Sanjaya & MY, RL \\
Nuwara Eliya & Seetaeliya & Lanka Butter & MY, RL \\
Nuwara Eliya & Norwood & Lanka Butter & BY, R, RL \\
Nuwara Eliya & Kandapola & Lanka Butter & BY, R, RL \\
Nuwara Eliya & Ambewela & Top Crop & MY, RL \\
Nuwara Eliya & Pattipola & Contender & MY, RL \\
Badulla & Bandarawela & Unknown & BY, R, RL \\
Badulla & Passara & Unknown & MY \\
Badulla & Demodara & Sanjaya & BY, R, RL \\
Badulla & Koslanda & Unknown & BY, R, RL \\
Badulla & Welimada & Top Crop & BY, R, RL \\
\hline BY-bright & Rera &
\end{tabular}

BY- bright yellow; R- rugose; MY- mild yellow; RL- reduced leaf size

\section{Host range study}

Among the species tested for susceptibility, only Ageratum sp., Glycine max, Macrotyloma uniflorum, Phaseolus lunatus and P. vulgaris L. (Table 2) showed symptoms characteristic of virus disease. Among them, G. max, M. uniflorum, P. lunatus and P. vulgaris showed incipient symptoms of yellow mosaic virus on leaves, while Ageratum spp. showed mild crinkling of leaves with no progression towards yellowing. The single directional sequence data of the DNA extracted from these hosts showing symptoms confirmed that HgYMV had been successfully transmitted from the original host. The sequence data were identical to the data reported previously by the same authors (Rienzie et al., 2016), and therefore there was no need to repeat it in the current work.

Host range of a virus is determined by two major factors, specifically those intrinsic factors such as genetic traits that determine the fitness of the virus in different hosts, and extrinsic factors independent of the virus such as ecological factors like distribution, abundance and interaction of species. As a result of the interaction between intrinsic and extrinsic factors, virus emergence and adaptation to new hosts takes place (McLeish et al.,
2018). Almost all the plant families tested in this study for cross transmission have been reported by many workers as likely hosts of begomoviruses (Nene, 1972; Shivanathan, 1983; Harrison, 1985). In this study, HgYMV was able to transmit the virus to Ageratum spp. According to Saunders et al. (2002), Ageratum conizoides behaves as a host to the Sri Lankan cassava mosaic virus. However, Muniyappa et al. (2003) reported that Ageratum conizoides does not host Pumpkin yellow vein mosaic virus (PYVMV), implying that Ageratum spp. does not host certain begomoviruses, showing selectivity towards hosting. Currently, Ageratum spp. with viruslike-symptoms is typical throughout Sri Lankan crop fields. However, the virus transmission behaviour from Ageratum to any other crop has not yet been studied in Sri Lanka. Unlike in the case of dicot plants, there is no evidence of infection of monocots by begomoviruses in literature. Supporting evidence on the cross transmission of HgYMV has been revealed through several studies. For instance, Rienzie et al. (2017) detected HgYMV in soybean (Glycine max) plants grown in experimental fields in Gannoruwa, Sri Lanka, and further identified Hedyotis corymbosa as a weed that harboured HgYMV (Rienzie et al., 2016). Moreover, Abarshi et al. (2017) detected the same virus in lima bean (Phaseolus lunatus) in Bangalore, India. Although only a minimum number 
Table 2: Results of the host range experiment for transmission of HgYMV

\begin{tabular}{|c|c|c|c|}
\hline Plant species & Family & $\begin{array}{l}\text { Number of plants } \\
\text { infected/inoculated } \\
\text { (percent infection) }\end{array}$ & $\begin{array}{c}\text { Control }^{\mathrm{c}} \\
\text { (percent infection) }\end{array}$ \\
\hline Abelmoschus esculentus & Malvaceae & & \\
\hline var. Haritha & & $0 / 5(0 \%)$ & $0 / 5(0 \%)$ \\
\hline var. MI 7 & & $0 / 5(0 \%)$ & $0 / 5(0 \%)$ \\
\hline Acalypha indica & Euphorbiaceae & $0 / 15(0 \%)$ & $0 / 5(0 \%)$ \\
\hline Ageratum spp. & Compositae & $2 / 10^{\mathrm{a}}(20 \%)$ & $0 / 5(0 \%)$ \\
\hline Allium cepa $\mathrm{L}$. & Liliaceae & $0 / 20(0 \%)$ & $0 / 5(0 \%)$ \\
\hline Amaranthus caudatus L. & Amaranthaceae & $0 / 15(0 \%)$ & $0 / 5(0 \%)$ \\
\hline Arachis hypogaea L. & Fabaceae & $0 / 20(0 \%)$ & $0 / 5(0 \%)$ \\
\hline Benincasa hispida (Thunb.) Cogn. & Cucurbitaceae & $0 / 10(0 \%)$ & $0 / 5(0 \%)$ \\
\hline Beta vulgaris L. & Chenopodiaceae & $0 / 10(0 \%)$ & $0 / 5(0 \%)$ \\
\hline Borreria spp. & Rubiaceae & $0 / 10(0 \%)$ & $0 / 5(0 \%)$ \\
\hline Brassica oleraceae $\mathrm{L}$. & Brassicaceae & $0 / 10(0 \%)$ & $0 / 5(0 \%)$ \\
\hline Cajanus cajan $\mathrm{L}$. & Fabaceae & $0 / 10(0 \%)$ & $0 / 5(0 \%)$ \\
\hline Calopogonium mucunoides & Fabaceae & $0 / 10(0 \%)$ & $0 / 5(0 \%)$ \\
\hline Canavalia spp. & Fabaceae & $0 / 10(0 \%)$ & $0 / 5(0 \%)$ \\
\hline Capsicum annuиm $\mathrm{L}$. & Solanaceae & $0 / 10(0 \%)$ & $0 / 5(0 \%)$ \\
\hline Centrocema pubescence & Fabaceae & $0 / 10(0 \%)$ & $0 / 5(0 \%)$ \\
\hline Citrullus vulgaris Schrad. & Cucurbitaceae & $0 / 10(0 \%)$ & $0 / 5(0 \%)$ \\
\hline Crotolaria juncea Neck. & Fabaceae & $0 / 10(0 \%)$ & $0 / 5(0 \%)$ \\
\hline Cucumis melo L. & Cucurbitaceae & $0 / 10(0 \%)$ & $0 / 5(0 \%)$ \\
\hline Cucumis pubescens & Cucurbitaceae & $0 / 10(0 \%)$ & $0 / 5(0 \%)$ \\
\hline Cucumis sativus L. & Cucurbitaceae & $0 / 10(0 \%)$ & $0 / 5(0 \%)$ \\
\hline Cucurbita maxima Duch. & Cucurbitaceae & $0 / 10(0 \%)$ & $0 / 5(0 \%)$ \\
\hline Cucurbita moschata Duch. Ex Poir & Cucurbitaceae & $0 / 10(0 \%)$ & $0 / 5(0 \%)$ \\
\hline Cucurbita pepo L. & Cucurbitaceae & $0 / 10(0 \%)$ & $0 / 5(0 \%)$ \\
\hline Daucus carota $\mathrm{L}$. & Apiaceae & $0 / 10(0 \%)$ & $0 / 5(0 \%)$ \\
\hline Dolichos trilobus & Fabaceae & $0 / 10(0 \%)$ & $0 / 5(0 \%)$ \\
\hline Eleusine coracana Gaertn. & Poaceae & $0 / 10(0 \%)$ & $0 / 5(0 \%)$ \\
\hline Emilia sonchifolia & Asteraceae & $0 / 10(0 \%)$ & $0 / 5(0 \%)$ \\
\hline Euphorbia heterophylla & Euphorbiaceae & $0 / 10(0 \%)$ & $0 / 5(0 \%)$ \\
\hline Glycine max Merrill. & Fabaceae & $11 / 15^{\mathrm{a}}(73.3 \%)$ & $0 / 5(0 \%)$ \\
\hline Gossypium barbadense L. & Malvaceae & $0 / 10(0 \%)$ & $0 / 5(0 \%)$ \\
\hline Helianthus annuus L. & Asteraceae & $0 / 10(0 \%)$ & $0 / 5(0 \%)$ \\
\hline Lablab purpureus L. & Fabaceae & $0 / 10(0 \%)$ & $0 / 5(0 \%)$ \\
\hline Lagenaria siceraria (Mol.) Standl. & Cucurbitaceae & $0 / 10(0 \%)$ & $0 / 5(0 \%)$ \\
\hline Luffa acutangula (L.) Roxb. & Cucurbitaceae & $0 / 10(0 \%)$ & $0 / 5(0 \%)$ \\
\hline Luffa cylindrica (L.) Roem. & Cucurbitaceae & $0 / 10(0 \%)$ & $0 / 5(0 \%)$ \\
\hline Lycopersicon esculentum Mill. & Solanaceae & & \\
\hline var. Thilina & & $0 / 10(0 \%)$ & $0 / 5(0 \%)$ \\
\hline var. Rajitha & & $0 / 10(0 \%)$ & $0 / 5(0 \%)$ \\
\hline var. T 245 & & $0 / 10(0 \%)$ & $0 / 5(0 \%)$ \\
\hline Macrotyloma uniflorum (Lam.) Verdc. & Fabaceae & $13 / 15^{\mathrm{a}}(86.7 \%)$ & $0 / 5(0 \%)$ \\
\hline Manihot esculenta Crantz & Euphorbiaceae & $0 / 8(0 \%)$ & $0 / 5(0 \%)$ \\
\hline Momordica charantia L. & Cucurbitaceae & $0 / 10(0 \%)$ & $0 / 5(0 \%)$ \\
\hline Mucuna spp. & Fabaceae & $0 / 10(0 \%)$ & $0 / 5(0 \%)$ \\
\hline Phaseolus lunatus $\mathrm{L}$. & Fabaceae & $3 / 5(60 \%)$ & $0 / 5(0 \%)$ \\
\hline
\end{tabular}

Continued - 
- continued from page 86

\begin{tabular}{llcc}
\hline Plant species & Family & $\begin{array}{c}\text { Number of plants } \\
\text { infected/inoculated } \\
\text { (percent infection) }\end{array}$ & $\begin{array}{c}\text { Control }^{\text {c }} \\
\text { (percent infection) }\end{array}$ \\
\hline Phaseolus vulgaris L. & Fabaceae & & \\
var. Keppetipola Nil & & $10 / 10^{\mathrm{b}}(100 \%)$ & $0 / 5(0 \%)$ \\
var. Contender & & $9 / 10^{\mathrm{a}}(90 \%)$ & $0 / 5(0 \%)$ \\
var. Sanjaya & & $10 / 10^{\mathrm{b}}(100 \%)$ & $0 / 5(0 \%)$ \\
var. Top Crop & $10 / 10^{\mathrm{a}}(100 \%)$ & $0 / 5(0 \%)$ \\
Phorocarpus tetragonolobus & Fabaceae & $0 / 10(0 \%)$ & $0 / 5(0 \%)$ \\
Raphanus sativus L. & Brassicaceae & $0 / 10(0 \%)$ & $0 / 5(0 \%)$ \\
Sesamum indicum L. & Pedaliaceae & $0 / 10(0 \%)$ & $0 / 5(0 \%)$ \\
Sida spp. & Malvaceae & $0 / 10(0 \%)$ & $0 / 5(0 \%)$ \\
Solanum melongena L. & Solanaceae & $0 / 10(0 \%)$ & $0 / 5(0 \%)$ \\
Sorghum bicolor L. & Poaceae & $0 / 10(0 \%)$ & $0 / 5(0 \%)$ \\
Trichosanthes cucumerina & Cucurbitaceae & $0 / 10(0 \%)$ & $0 / 5(0 \%)$ \\
Vigna mungo L. & Fabaceae & $0 / 10(0 \%)$ & $0 / 5(0 \%)$ \\
Vigna radiata (L.) Wilczek & Fabaceae & $0 / 10(0 \%)$ & $0 / 5(0 \%)$ \\
Vigna ungiculata (L.) Walp. & Fabaceae & $0 / 10(0 \%)$ & $0 / 5(0 \%)$ \\
Vigna ungiculata (L.) & Fabaceae & $0 / 10(0 \%)$ & $0 / 5(0 \%)$ \\
Vigna ungiculata (L.) var. sesquipedalis & Fabaceae & $0 / 10(0 \%)$ & $0 / 5(0 \%)$ \\
\hline
\end{tabular}

${ }^{a}$ Confirmed through PCR only; ${ }^{b}$ confirmed through both PCR followed by partial sequencing; ${ }^{\mathrm{c}}$ control experiment was performed by inoculation with non-viruliferous $B t$ at a rate of $10 \mathrm{Bt}$ per plant

of inoculated test plants was infected with HgYMV in this study, further studies are needed to understand the reaction of other legume weeds to $\mathrm{HgYMV}$, since there is a possibility of new plant species becoming hosts for the begomovirus.

\section{Relative transmission efficiency}

Relative transmission efficiency was tested by inoculating healthy common bean plants with viruliferous $B t$ and the result was calculated as $96.7 \%($ S.E. $= \pm 5.77)$ with $p^{*}=0.24$. Available literature provides details about different efficiencies with respect to different Bemisia tabaci transmitted viruses. Prema (2013) observed that HgYMV transmission occurs at a range of 6-86\% under field conditions. According to Mware et al. (2009), the transmission percentage of Cassava brown streak virus is $22 \%$ although the $B t$ were allowed 48 hours AAP. Reasons for higher transmission efficiency for $B t$ in the present experiment could be due to forced feeding under confined spaces. Based on the results of the present study, it could be observed that the incidence of disease increases with the increased numbers of $B t$ per common bean plant. Similar results have been reported with the same whitefly species for Mung bean yellow mosaic virus (MYMV) in India (Nene, 1972), for leaf curl virus of Zinnia elegans in India (Mathur, 1933), for Bhindi yellow vein mosaic virus (BYVMV) in India (Varma, 1952), and for Tomato yellow leaf curl virus (TYLCV) (Cohen \& Nitzany, 1966).

Table 3: Transmission percentages with different numbers of $B t$

\begin{tabular}{ccc}
\hline $\begin{array}{l}\text { Number of } B t \\
\text { per plant }\end{array}$ & $\begin{array}{c}\text { Average percent of } \\
\text { infected plants }\end{array}$ & $\mathrm{p}^{*}$ \\
\hline & $36.7^{\mathrm{a}}( \pm 3.3)$ & 0.37 \\
3 & $53.3^{\mathrm{b}}( \pm 6.7)$ & 0.22 \\
5 & $86.7^{\mathrm{c}}( \pm 6.7)$ & 0.33 \\
10 & $100^{\mathrm{d}}( \pm 0.0)$ & 1.00 \\
15 & $100^{\mathrm{d}}( \pm 0.0)$ & 1.00 \\
20 & $100^{\mathrm{d}}( \pm 0.0)$ & 1.00 \\
25 & $100^{\mathrm{d}}( \pm 0.0)$ & 1.00 \\
CV & 7.96 & \\
LSD & 11.48 & \\
\hline
\end{tabular}

Means with the same letter along the column are not significantly different from each other according to least significant difference (LSD) at $\mathrm{p}<0.05$. Data expressed as mean $( \pm)$ standard error $(\mathrm{n}=3), \mathrm{CV}=$ coefficient of variation, $\mathrm{p}^{*}=$ estimated transmission rate for a single whitefly. 
Minimum number of Bemisia tabaci required for successful transmission

Results for the different numbers of $B t$ insects ranging from 1 to 25 , which were fed on infected common bean leaves for 24 hours AAP and then transferred onto healthy common bean seedlings for another $24 \mathrm{~h}$ IAP are given in Table 3 .

When the plants were inoculated with a single viruliferous whitefly, the disease incidence was $36.7 \%\left(\mathrm{p}^{*}=0.37\right)$, indicating that the disease could be transmitted even due to the feeding of a single viruliferous whitefly. Similar results have been reported by Nene (1972), Muniyappa et al. (2003), and Reddy (2006) for MYMV, PYVMV and Tomato leaf curl virus (ToLCV), respectively. Light intensity may change the behaviour of insects, probably by affecting the feeding efficiency (Mware et al., 2009) and the desire to feed. When plants were inoculated with 15 or more viruliferous $B t$ per plant, initial symptoms appeared within 12-13 days. However, with 10 or fewer viruliferous $B t$ per plant, it took more than 14 days for symptoms to appear. In plants inoculated with a single whitefly, the amount of virus particles entering at a time is lower, whereas increased numbers of $B t$ lead to the accumulation of more virus particles, resulting in increased viral loading within the tissues. Therefore, plants inoculated with a single viruliferous $B t$ may show symptoms with a lower severity and lower incidence than those inoculated with more viruliferous Bt. Generally, plant defense mechanisms trigger reactions against the invasion of any virus. Such mechanisms cause the production of different chemical compounds by plant tissues that inhibit the activity of the virus.

\section{Minimum acquisition access period (AAP) of Bemisia tabaci for HgYMV}

Viruliferous $B t$ with different AAPs of 5 minutes to 48 hours were released onto healthy seedlings and percent infections were recorded in all three replicates. Disease incidences resulting from different AAPs as given in Table 4 indicate that the $B t$ can effectively acquire the virus from infected common beans within a minimum period of 20 minutes. No symptoms appeared on healthy bean plants inoculated for 5, 10 and 15 minutes, indicating that the whiteflies were not able to acquire the virus by feeding on infected bean plants for less than 15 minutes.
Table 4: Acquisition access periods (AAPs) of Bemisia tabaci for HgYMV

\begin{tabular}{lcc}
\hline $\begin{array}{l}\text { Feeding period on } \\
\text { infected beans }\end{array}$ & Percent infection & $\mathrm{p}^{*}$ \\
\hline $5 \mathrm{~min}$ & $0.0^{\mathrm{a}}$ & 0.00 \\
$10 \mathrm{~min}$ & $0.0^{\mathrm{a}}$ & 0.00 \\
$15 \mathrm{~min}$ & $0.0^{\mathrm{a}}$ & 0.00 \\
$20 \mathrm{~min}$ & $30.0^{\mathrm{b}}( \pm 10.0)$ & 0.04 \\
$30 \mathrm{~min}$ & $43.3^{\mathrm{cb}}( \pm 3.3)$ & 0.06 \\
1 hour & $56.7^{\mathrm{c}}( \pm 10.0)$ & 0.09 \\
2 hours & $60.0^{\mathrm{c}}( \pm 8.80)$ & 0.08 \\
4 hours & $80.0^{\mathrm{d}}( \pm 5.8)$ & 0.15 \\
6 hours & $86.7^{\mathrm{ed}}( \pm 8.8)$ & 0.18 \\
8 hours & $86.7^{\mathrm{ed}}( \pm 3.3)$ & 0.18 \\
24 hours & $93.3^{\text {ed }}( \pm 3.3)$ & 0.24 \\
48 hours & $93.3^{\text {ed }}( \pm 3.3)$ & 1.00 \\
LSD & 19.12 & \\
CV & 16.64 & \\
\hline
\end{tabular}

Means with the same letter are not significantly different according to least significant difference (LSD) at $(p<0.05)$. Data expressed as mean $( \pm)$ standard error $(n=3) ; C V=$ coefficient of variation; $\mathrm{p}^{*}=$ estimated transmission rate for a single whitefly.

Table 5: Inoculation access periods (IAPs) of Bemisia tabaci for HgYMV

\begin{tabular}{lcc}
\hline $\begin{array}{l}\text { Feeding period } \\
\text { on healthy beans }\end{array}$ & Percent infection & $\mathrm{p}^{*}$ \\
\hline $5 \mathrm{~min}$ & $0.0^{\mathrm{a}}$ & 0.00 \\
$10 \mathrm{~min}$ & $0.0^{\mathrm{a}}$ & 0.00 \\
$15 \mathrm{~min}$ & $0.0^{\mathrm{a}}$ & 0.00 \\
$20 \mathrm{~min}$ & $36.7^{\mathrm{b}}( \pm 3.3)$ & 0.05 \\
$30 \mathrm{~min}$ & $40.0^{\mathrm{bc}}( \pm 5.8)$ & 0.05 \\
1 hour & $53.3^{\mathrm{ed}}( \pm 8.8)$ & 0.07 \\
2 hours & $63.3^{\mathrm{dc}}( \pm 8.8)$ & 0.01 \\
4 hours & $66.7^{\mathrm{ed}}( \pm 3)$. & 0.10 \\
6 hours & $76.7^{\mathrm{fe}}( \pm 8.8)$ & 0.14 \\
8 hours & $83.3^{\mathrm{gf}}( \pm 8.8)$ & 0.16 \\
24 hours & $100.0^{\mathrm{h}}( \pm 0.0)$ & 1.00 \\
48 hours & $96.7^{\mathrm{hg}}( \pm 3.3)$ & 0.29 \\
LSD & 17.31 & \\
CV & 14.73 & \\
\end{tabular}

Means with the same letter are not significantly different from each other according to least significant difference $(\mathrm{LSD})$ at $(\mathrm{p}<0.05)$. Data are expressed as mean $( \pm)$ standard error $(n=3)$; $C V=$ coefficient of variation; $\mathrm{p}^{*}=$ estimated transmission rate for a single whitefly. 


\section{Minimum inoculation access period (IAP)}

Results revealed that the viruliferous $B t$ are able to transmit the virus into a healthy common bean seedling within a minimum of 20 minutes (Table 5). The disease incidence reached $100 \%$ with an IAP of 6 hours. The failure to develop the disease when the whiteflies feed for 5-15 minutes on healthy bean plants indicates that the vectors are unable to transmit the virus when feeding time is less than 15 minutes.

Many researchers have reported that AAPs and IAPs fall within the range of 15-30 minutes for various $B t$ transmitted viruses and that they can notice regional differences. Accordingly, a minimum of 15 minutes was reported for MYMV in terms of both AAP and IAP (Nene, 1972) in India. In another case of HgYMV, 30 minutes each in AAP and IAP were reported by Muniyappa and Reddy (1976), also from India. Similarly, 30 minutes each for AAP and IAP have been reported by Mansur and Al-Musa (1992) from Jordan, Ioannou (1985) from the Middle East, Caciagli et al. (1995) in Italy, and Muniyappa et al. (2000) in India for TYLCV. Furthermore, Reddy and Yaraguntaiah (1981) for ToLCV and Muniyappa et al. (2003) for PYVMV have also reported similar results in India.
In contrast to the above results, minimum AAP and minimum IAP have been reported as 1 hour and 2 hours, respectively for TYLCV by Brown and Nelson (1988). Interestingly, Senanayake et al. (2012) reported minimum AAP and IAP of 3 hours and 1 hour, respectively for Chilli leaf curl virus in India. The values in the above two cases are much higher than the present experimental values obtained. No symptoms were observed in the healthy bean plants fed by $B t$ for less than the minimum AAP reported in this experiment (20 minutes). However, various researchers have confirmed the presence of certain begomoviruses in $B t$ insects even when they fed on the infected plants for only 5-10 minutes; but this happened mainly when they used either molecular or serological means for assessment (Navot et al., 1992; Atzmon et al., 1998; Ghanim et al., 2001).

In most cases, the reported AAPs are higher than the IAP. According to Costa (1976), one reason for this might be insufficient time for the stylet of the vector to reach into the susceptible tissues in the phloem; another reason could be the long time feeding requirement of $B t$ vector to become infective and increase its chance of transmission.

Table 6: Persistence of virus in Bemisia tabaci during a serial transfer of $\mathrm{HgYMV}$ to common bean plants

\begin{tabular}{|c|c|c|c|c|c|c|c|c|c|c|c|c|}
\hline \multirow{2}{*}{$\begin{array}{l}\text { Test } \\
\text { group }\end{array}$} & \multirow[b]{2}{*}{$\mathrm{D}_{1}$} & \multicolumn{10}{|c|}{ Serial transfer of Bemisia tabaci insects at 24 hour intervals $\left(D_{1}-D_{12}\right)$} & \multirow[b]{2}{*}{$\%$ Infection } \\
\hline & & $\mathrm{D}_{2}$ & $\mathrm{D}_{3}$ & $\mathrm{D}_{4}$ & $\mathrm{D}_{5}$ & $\mathrm{D}_{6}$ & $\mathrm{D}_{7}$ & $\mathrm{D}_{8}$ & $\mathrm{D}_{9}$ & $\mathrm{D}_{10}$ & $\mathrm{D}_{11}$ & \\
\hline 1 & $\neg$ & + & - & + & + & - & + & - & $\mathrm{d}$ & & & 57.1 \\
\hline 2 & + & + & + & + & + & + & - & - & $\mathrm{d}$ & & & 75.0 \\
\hline 3 & + & + & + & + & + & + & + & + & + & $\mathrm{d}$ & & 100 \\
\hline 4 & + & + & + & + & - & + & + & + & - & $\mathrm{d}$ & & 77.8 \\
\hline 5 & + & + & + & + & + & + & + & $\mathrm{d}$ & & & & 100.0 \\
\hline 6 & + & + & + & + & + & + & + & - & + & $\mathrm{d}$ & & 88.9 \\
\hline 7 & + & - & + & + & + & + & $\mathrm{d}$ & & & & & 83.3 \\
\hline 8 & + & - & - & + & - & + & + & d & & & & 57.1 \\
\hline 9 & + & + & + & - & + & + & - & d & & & & 71.4 \\
\hline 10 & + & - & + & - & + & $\mathrm{d}$ & & & & & & 60.0 \\
\hline 11 & + & - & + & + & + & - & - & + & + & - & d & 45.5 \\
\hline 12 & + & + & + & + & + & - & + & - & $d$ & & & 75.0 \\
\hline $\begin{array}{l}\text { Daily } \\
\text { average \% } \\
\text { infection }\end{array}$ & 100 & 58.3 & 91.6 & 83.3 & 75.0 & 81.8 & 50.0 & 50.0 & 50.0 & - & - & \\
\hline
\end{tabular}

+ Symptoms appeared; - Symptoms did not appear; d - Death of last Bt of 12 Bt group 


\section{Persistence of the virus in the Bemisia tabaci insects}

In this study, the virus persisted in the whitefly vector for a maximum of 9 days irrespective of the sex of the insects, further confirming the possibility of horizontal transfer of the virus. Similarly, Muniyappa et al. (2003) also reported the persistence of PYVMV for 8 days. When comparing the serial transmission rates between test groups it was found that they ranged from $45.4 \%$ (minimum) to $100 \%$ (maximum). The average infection rate per group was calculated to be $74.3 \%$ per group of $B t$ insects. Furthermore, when comparing the time lapsed with infection strength, it varied from $50 \%$ (minimum resulted on $8^{\text {th }}$ day and $9^{\text {th }}$ day) to $100 \%$ (maximum resulted on $1^{\text {st }}$ day). An overall pattern of decreasing trend in infection was observed with the increase in time (Table 6). Higher persistence of the virus, lasting for more than 9 days would have been achieved if there were only female insects or a high proportion of females in the transfer groups and with higher survival rates as observed by Nene (1972) and Muniyappa et al. (2003). As the whiteflies were used without segregating them by sex, its influence on infection could not be clearly determined. Furthermore, it must be mentioned that in this study, the vertical transfer ability was not studied. Except for one or two cases including Tomato yellow leaf curl virus (TYLCV), which had been widely studied for transovarial transmission (Wei et al., 2017; Bosco et al., 2004), there is no evidence of the same phenomenon occurring in the majority of begomoviruses transmitted by $B$. tabaci. Accordingly, it has been demonstrated that transmission of viral DNA through vector eggs and subsequent nymphal stages is a relatively common phenomenon (Accotto \& Sardo, 2010; Bosco et al., 2014; Guo et al., 2019).

\section{CONCLUSION}

Among the 54 plant species tested for their hosting ability, only a few plant species, namely, Ageratum sp., G. max, and M. uniflorum were susceptible to HgYMV while none of the tested monocots showed susceptibility to it. Bemisia tabaci Genn. was efficient at transmitting HgYMV causing yellowing disease in common beans, with successful transmission being achieved even through a single viruliferous whitefly. Minimum acquisition access period and minimum inoculation access period were 20 minutes in both cases and the virus could be retained by Bemisia tabaci for up to nine days after acquisition. The transmission characteristics lay within the typical ranges reported for begomoviruses around the world, especially in India but were lower than those reported in the Middle East and Mediterranean countries. The characteristics determined in the present study may differ if tests are repeated under field conditions. Furthermore, the present work emphasises the importance of considering all relevant aspects including the nature of hosts when managing viral diseases.

\section{Acknowledgements}

The authors gratefully acknowledge the assistance of the research staff of both the Plant Pathology and Entomology Divisions, Horticultural Crop Research and Development Institute, Department of Agriculture, Gannoruwa, Peradeniya. The authors also express their thanks to the technical staff and research students of the Department of Agricultural Biology Faculty of Agriculture, University of Peradeniya, for the immense technical support they provided.

\section{REFERENCES}

Abarshi M.M., Abubakar A.L., Garba A., Mada S.B., Ibrahim A.B. \& Maruthi M.N. (2017). Molecular detection and characterisation of Horsegram yellow mosaic virus (HgYMV) infecting lima bean (Phaseolus lunatus) in India. Nigerian Journal of Biotechnology 33(1): 41-48. DOI: https://doi.org/10.4314/njb.v33i1.6

Accotto G.P. \& Sardo L. (2009). Transovarial transmission of begomoviruses in Bemisia tabaci. In: Bemisia: Bionomics and Management of a Global Pest, pp. 339-345. Springer, Dordrecht, Germany.

DOI: https://doi.org/10.1007/978-90-481-2460-2_12

Andret-Link P. \& Fuchus M. (2005). Transmission specificity of plant viruses by vectors. Journal of Plant Pathology 87(3): 153-165.

Atzmon G., van Hoss H. \& Czosnek H., (1998). PCRamplification of Tomato yellow leaf curl virus (TYLCV) from squashes of plants and insect vectors: application to the study of TYLCV acquisition and transmission. European Journal of Plant Pathology 104: 189-194.

DOI: https://doi.org/10.1023/A:1008699603559

Bosco D., Mason G. \& Accotto G.P. (2004). TYLCSV DNA, but not infectivity, can be transovarially inherited by the progeny of the whitefly vector Bemisia tabaci (Gennadius) Virology 323: 276-283.

DOI: https://doi.org/10.1016/j.virol.2004.03.010

Briddon R., Mansoor S., Bedford I.D., Pinner M.S., Saunders K., Stanley J., Zafar Y., Malik K.A. \& Markham P.G. (2001). Identification of DNA components required for induction of cotton leaf curl disease. Virology 285: 234-243. DOI: https://doi.org/10.1006/viro.2001.0949

Brown J.K. \& Nelson M.R. (1988). Transmission, host range and virus-vector relationships of Chino del tomato virus, a whitefly-transmitted geminivirus from Sinaloa, Mexico. Plant Disease 72: 866-869. 
DOI: https://doi.org/10.1094/PD-72-0866

Caciagli P., Bosco D. \& Al-Bitar L. (1995). Relationships of the Sardinian isolate of Tomato yellow leaf curl geminivirus with its whitefly vector Bemisia tabaci Gen. European Journal of Plant Pathology 101: 163-170.

DOI: https://doi.org/10.1007/BF01874762

Cohen S. \& Nitzany F.E. (1966). Transmission and host range of the Tomato yellow leaf curl virus. Phytopathology 56:1127-1131.

Costa A.S. (1976). Whitefly-transmitted plant diseases. Annual Review of Phytopathology 14: 429-449.

DOI: https://doi.org/10.1146/annurev.py.14.090176.002241

Deng A., McGrath P.F., Robinson D.J. \& Harrison B.D. (1994). Detection and differentiation of whitefly transmitted geminiviruses in plants and vector insects by the polymerase chain reaction with degenerate primers. Annals of Applied Biology 125: 327-336.

DOI: https://doi.org/10.1111/j.1744-7348.1994.tb04973.x

Ghanim M., Morin S. \& Czosnek H. (2001). Rate of Tomato yellow leaf curl virus (TYLCV) translocation in the circulative transmission pathway of its vector, the whitefly Bemisia tabaci. Phytopathology 91: 188-196.

DOI: https://doi.org/10.1094/PHYTO.2001.91.2.188

Gibbs A.J. \& Gower J.C. (1960). The use of multiple-transfer method in plant virus transmission studies-some statistical points arising in the analysis of results. Annals of Applied Biology 48: 75-83.

DOI: https://doi.org/10.1111/j.1744-7348.1960.tb03506.x

Guo Q., Shu Y.N., Liu C., Chi Y., Liu Y.Q. \& Wang X.W. (2019). Transovarial transmission of Tomato yellow leaf curl virus by seven species of the Bemisia tabaci complex indigenous to China: not all whiteflies are the same. Virology 531: 240-247.

DOI: https://doi.org/10.1016/j.virol.2019.03.009

Harrison B.D. (1985). Advances in geminivirus research. Annual Review of Phytopathology 23: 55-82.

DOI: https://doi.org/10.1146/annurev.py.23.090185.000415

Inoue-Nagata A.K., Nagata T., de Ávila A.C. \& Giordano L.D.B. (2007). A reliable begomovirus inoculation method for screening Lycopersicon esculentum lines. Horticultura Brasileira 25(3): 447-450. DOI: https://doi.org/10.1590/S0102-05362007000300024

Ioannou N. (1985). Yellow leaf curl and other diseases of tomato in Cyprus. Plant Pathology 345: 428-434. DOI: https://doi.org/10.1111/j.1365-3059.1985.tb01383.x

Legg J.P. \& Fauquet C.M. (2004). Cassava mosaic gemini viruses in Africa. Plant Molecular Biology 56(4): 585-599. DOI: https://doi.org/10.1007/s11103-004-1651-7

Lodhi M.A., Ye G.N., Weeden N.F. \& Reisch B.I. (1994). A simple and efficient method for DNA extraction from grapevine cultivars and Vitis species. Plant Molecular Biology Reporter 12(1): 6-13.

DOI: https://doi.org/10.1007/BF02668658

Mansour A. \& Al-Musa A. (1992). Tomato yellow leaf curl virus: host range and vector-virus relationships. Plant Pathology 41: 122-125.

DOI: https://doi.org/10.1111/j.1365-3059.1992.tb02328.x
Mathur P.N. (1933). Leaf curl virus in Zinnia elegans at Deharadun. Indian Journal of Agricultural Sciences 3: 89-96.

McLeish M.J., Fraile A. \& Garcia-Arenal F. (2018). Ecological complexity in plant virus host range evolution. Advances in Virus Research 101: 293-339.

Monger W.A., Harju V., Nixon T., Bennett S., Reeder R., Kelly P. \& Ariyarathne H.M. (2010). First report of Horsegram yellow mosaic virus infecting Phaseolus vulgaris in Sri Lanka. New Disease Reports 21: 16.

DOI: https://doi.org/10.5197/j.2044-0588.2010.021.016

Muniyappa V., Maruthi M.N., Babitha C.R., Colvin J., Briddon R.W. \& Rangaswamy K.T. (2003). Characterization of Pumpkin yellow vein mosaic virus from India. Annals of Applied Biology 142: 323-331.

DOI: https://doi.org/10.1111/j.1744-7348.2003.tb00257.x

Muniyappa V., Rajeshwari R., Bharathan N., Reddy D.V.R. \& Nolt B.L. (1987). Isolation and characterization of a geminivirus causing yellow mosaic disease of horsegram [Macrotyloma uniflorum (Lam.) Verdc.] in India. Journal of Phytopathology 119: 81-87.

DOI: https://doi.org/10.1111/j.1439-0434.1987.tb04386.x

Muniyappa V. \& Reddy H.R. (1976). Studies on the yellow mosaic disease of horsegram (Dolichos biflorus Linn.), virus-vector relationship. Mysore Journal of Agricultural Sciences 10: 605-610.

Muniyappa V., Venkatesh H.M., Ramappa H.K., Kulkarni R.S., Zeidan M., Tarba C.Y., Ghanim M. \& Czosnek H. (2000). Tomato leaf curl virus from Bangalore (ToLCVBan4): sequence comparison with Indian ToLCV isolates, detection in plants and insects and vector relationships. Archives of Virology 145: 1583-1598.

Mware B., Narla R., Amata R., Olubayo F., Songa J., Kyamanyua S. \& Ateka E.M. (2009). The efficiency of Cassava brown streak virus (CBSV) transmission by Bemisia tabaci (Gennadius). Journal of General and Molecular Virology 1(4): 40-45.

DOI: https://doi.org/10.1007/s007050070078

Navas-Castillo J., Fiallo-Olive E. \& Sanchez-Campos S. (2011). Emerging virus diseases transmitted by Bemisia tabaci. Annual Review of Phytopathology 49(15): 1-15. DOI: https://doi.org/10.1146/annurev-phyto-072910-095235

Navot N., Zeidan M., Pichersky E., Zamir D. \& Czosnek H. (1992). Use of polymerase chain reaction to amplify Tomato yellow leaf curl virus DNA from infected plants and viruliferous Bemisia tabaci. Phytopathology 82: 11991202.

DOI: https://doi.org/10.1094/Phyto-82-1199

Nene Y.L. (1972). A Survey of Viral Diseases of Pulse Crops in Uttar Pradesh in India, pp. 191. G.B. Pant University of Agriculture and Technology Press, India.

Prema G.U. (2013). Molecular characterization of Horsegram yellow mosaic virus and its management. PhD thesis, University of Agricultural Sciences, Bengaluru, India.

Reddy B.A. (2006). Molecular Characterization, Epidemiology and Management of Tomato Leaf Curl Virus (Tolcv) in Northern Karnataka. Dharwad, India, PhD thesis, 
University of Agricultural Sciences

Reddy K.S. \& Yaraguntaiah R.C. (1981). Virus-vector relationship in leaf curl disease of tomato. Indian Phytopathology 34: 310-313.

Rienzie K.D.R.C., Wickramaarachchi W.A.R.T. \& de Costa D.M. (2016). Molecular detection and characterization of begomovirus causing bean yellowing disease in Sri Lanka. Journal of the National Science Foundation of Sri Lanka 44(3): 249-255.

DOI: https://doi.org/10.4038/jnsfsr.v44i3.8007

Rienzie K.D.R.C., Wickramaarachchi W.A.R.T. \& de Costa D.M. (2017). Partial molecular characterization and transmission of Horsegram yellow mosaic virus causing soybean yellowing disease, $6^{\text {th }}$ Young Scientists' Forum, National Science \& Technology Commission, Sri Lanka (ext. abst), pp.102-106.

Rojas M.R. et al. (20 authors) (2018). World management of Geminiviruses. Annual Review of Phytopathology 56: 637-677.

DOI: https://doi.org/10.1146/annurev-phyto-080615-100327

Saunders K., Nazeera S., Mali V.R., Malathi V.G., Briddon R., Markham P.G. \& Stanley J. (2002). Characterization of Sri Lankan cassava mosaic virus and Indian cassava mosaic virus: evidence for acquisition of a DNA B component by a monopartite begomovirus. Virology 293: 63-74.

DOI: https://doi.org/10.1006/viro.2001.1251

Senanayake D.M.J.B., Varma A. \& Mandal B. (2012). Virus- vector relationships, host range, detection and sequence comparison of Chilli leaf curl virus associated with an epidemic of leaf curl disease of chilli in Jodhpur, India. Journal of Phytopathology 160(3): 146-155.

DOI: https://doi.org/10.1111/j.1439-0434.2011.01876.x

Shivanathan P. (1983). The epidemiology of three viruses caused by whitefly borne pathogens. In: Plant Virus Epidemiology (eds. R.T. Plumb \& J.M. Thresh), pp. 323330. Blackwell Scientific Publications, Oxford, UK.

Varma P.M. (1952). Studies on the relationship of the Bhendi yellow vein mosaic virus and its vector, the whitefly (Bemisia tabaci Genn.). Indian Journal of Agricultural Science 22: 75-91.

Wei J., He Y.Z., Guo Q., Guo T., Liu Y.Q., Zhou X.P., Liu S.S. \& Wang X.W. (2017). Vector development and vitellogenin determine the transovarial transmission of begomoviruses. Proceedings of the National Academy of Sciences USA 114(26): 6746-6751.

DOI: https://doi.org/10.1073/pnas.1701720114

Wickramaarachchi W.A.R.T., Rajapakse R.G.A.S., Kumarage A.M., Samarawijaya A.P., Bandaranayake E. \& Premaratne P. (2012). Molecular detection of begomovirus associated with common bean yellowing disease in Sri Lanka. Annals of the Sri Lanka Department of Agriculture 14: 221-231.

William F.J., Grewal J.S. \& Amin K.S. (1968). Serious and new disease of pulse crops in India in 1966. Plant Disease Reporter 52: 300-304. 